\title{
Istraživanje kemijskog sastava plodova sorti višanja u ekologijskim uvjetima Slavonije
}

\author{
Research on chemical composition of sour cherry varieties \\ in ecological conditions of Slavonia
}

\section{Miljković}

\section{SAŽETAK}

Istraživanje kemijskog sastava plodova višanja: Gorsemska, Rexelle, Kelleris 14, Heimannova konzervna i Oblačinska, na podlozi divlje trešnje (Prunus avium L.), provedeno je tijekom tri godine u ekološkim uvjetima Slavonije. Istraživanjima je utvrđeno da najveću topivu suhu tvar, količinu ukupnog i reduktivnog šećera sadrže plodovi sorti Rexelle i Kelleris 14, a najmanje plodovi Oblačinske. Između sorti Rexelle i Kelleris 14 i ostale tri sorte utvrđena je statistički opravdana razlika. Podjednaku količinu topive suhe tvari sadrže plodovi sorti Gorsemska i Heimannova konzervna, dok je količina šećer nešto veća u sorte Gorsemska. Sorta Heimannova konzervna sadrži nešto više šećera nego Oblačinska, ali ta razlika nije statistički opravdana. Utvrđena je niska količina saharoze u plodovima istraživanih sorti. Razlika u količini saharoze među sortama nije statistički opravdana. Signifikantno više ukupnih kiselina sadrže plodovi sorti Gorsemska, Kelleris 14 i Oblačinske od plodova sorti Rexelle i Heimannova konzervna. Vrijednosti pH su se kretale u granicama od 3,01 do 3,24.

Ključne riječi: višnja, sorte, kemijski sastav plodova

\begin{abstract}
The study of the chemical composition of fruits cherries: Gorsemska, Rexelle, Kelleris 14, Heimanns Konserven and Oblačinska, on rootstock mazzard (Prunus avium L.), was conducted over the three year period in the environmental conditions of Slavonia. Research has shown that the maximum soluble dry matter, the total amount and a reducing sugar is contained in fruits of varieties Rexelle and Kelleris 14, and the least in fruits of variety Oblačinska. Significant difference was found among the varieties of Rexelle and Kelleris 14 and the remaining three varieties. Equal amounts of soluble solids are contained in fruits of varieties Gorsemska and Heimanns Konserven, while the little higher amount of sugar is found in variety Gorsemska. The variety Heimanns contained slightly more sugar than Oblačinska, but this difference was not statistically significant. A low amount of saccharose was found in fruits of investigated varieties. The difference found in the amount of saccharose among varieties was not
\end{abstract}


statistically justified. Significantly more of the total acids was contained in fruits varieties Gorsemska, Kelleris 14 and Oblačinska varieties then in fruits of varieties Rexelle and Heimanns. The $\mathrm{pH}$ values were in the range from 3,01 to 3,24.

Key words: sour cherry, varieties, chemical composition, fruits

\section{UVOD}

Plodovi višanja su vrlo cijenjeni za različite oblike prerade i potrošnju u svježem stanju. Koriste se za proizvodnju džema, slatkog, kompot, sirup, sok, likere itd. Puno su traženi na domaćem i stranom tržištu u svježem stanju ili kao smrznuti. Porastom kapaciteta za preradu i doradu raste i potražnja za kvalitetnim plodovima višanja. Kvaliteta višanja ovisi o genetskim osobinama sorte, ekologijskim uvjetima proizvodnog prostora i sustavu uzgoja. Poznato je da kvaliteta plodva višanja u velikoj mjeri ovisi o klimatskim prilikama. Ista sorta u ovisnosti o klimatskim prilikama odražava manje ili više razlike u kemijskom sastavu ploda. Uzgoj višnje u Slavoniji poznat je odavna, pa je proširena bogata autohtona populacija sjeverne domaće višnje. U novije vrijeme u uzgoju je prošireno više novih kvalitetnih sorti s kojima su postignuti dobri rezultati glede rodnosti i prilagodbe ekologijskim uvjetima Slavonije (Miljković, 1991.). Kako se kvaliteta ploda ocjenjuje u odnosu na kemijski sastav odlučili smo pridonijeti boljem poznavanju kemijskog sastava plodova za pet više proširenih sorti.

\section{OBJEKT ISTRAŽIVANJA I METODE RADA}

Istraživanja su obavljena sa sortama: Gorsemska, Rexelle, Kelleris 14, Heimannova konzervna i Oblačinska cijepljenih na podlogu divlje trešnje (Prunus avium L.) u ekologijskim uvjetima zapadne Slavonije. Voćnjak iz kojeg su uzimani uzorci plodova za kemijsku analizu, podignut je na dubokom dobro dreniranom aluvijalnom tlu. Klima je semihumidna sa srednjom godišnjom količinom padalina $788 \mathrm{~mm}$, a u periodu vegetacije $427 \mathrm{~mm}$. Hidrotermički koeficijent po Popovu iznosi 1,20. Srednja godišnja temperatura iznosi 11,0, a u periodu vegetacije $17,6{ }^{\circ} \mathrm{C}$. Ofóenito se može reći da su ekologijski uvjeti za uzgoj višanja vrlo povoljni. Za analizu kemijskog sastava plodova uzimano je za svaku sortu po 5 prosječnih uzoraka. Svaki je uzorak težio $1 \mathrm{~kg}$. Analiza kemijskog sastava plodva obuhvatila je: topivu suhu tvar, ukupne šećere, invertni šećer, saharozu, ukupne kiseline i pH vrijednost. Topiva suha tvar određena je sa Zeissovim refraktometrom. Ukupni i reduktivni šećeri određeni 
su gravimetrijskom metodom Fehloingovim otopinama. Količina ukupnih kiselina određena je titracijom s n/10 NaOH uz bromthymolblau, a izražen kao citronska kiselina. $\mathrm{pH}$ vrijednost određena je potencijometriski. Rezultati istraživanja obrađeni su varijaciono statistički analizom varijance.

\section{REZULTATI ISTRAŽIVANJA}

Rezultati trogodišnjih istraživanja izneseni su kao srednje vrijednosti na tablici 1.

\section{Tablica 1.: Kemijski sastav plodova sorti višanja}

Table 1 :Chemical composition of sour cherry varieties

\begin{tabular}{|l|c|c|c|c|c|c|}
\hline \multicolumn{1}{|c|}{$\begin{array}{c}\text { Sorta - } \\
\text { Variety }\end{array}$} & $\begin{array}{c}\text { Topiva suha } \\
\text { tvar u (in) \% } \\
\text { Soluble dry } \\
\text { matter }\end{array}$ & $\begin{array}{c}\text { Ukupni } \\
\text { šćer u \% } \\
\text { Total } \\
\text { sugar in \% }\end{array}$ & $\begin{array}{c}\text { Reduktivni } \\
\text { šcé u \% } \\
\text { Sugar } \\
\text { invert in \% }\end{array}$ & $\begin{array}{c}\text { Saharoza } \\
\text { u \%, } \\
\text { Saccharose } \\
\text { in \% }\end{array}$ & $\begin{array}{c}\text { Ukupne } \\
\text { kiseline u \%, } \\
\text { Total acids } \\
\text { in \% }\end{array}$ & pH \\
\hline Gorsemska & 15,00 & 8,85 & 8,58 & 0,27 & 1,78 & 3,06 \\
\hline Rexelle & 16,30 & 9,93 & 9,62 & 0,31 & 1,41 & 3,19 \\
\hline Kelleris 14 & 15,82 & 9,40 & 9,09 & 0,31 & 1,75 & 3,07 \\
\hline $\begin{array}{l}\text { Heimannova } \\
\text { konzervna }\end{array}$ & 15,0 & 8,58 & 8,21 & 0,37 & 1,40 & 3,24 \\
\hline Oblačinska & 13,40 & 8,33 & 8,02 & 0,31 & 1,77 & 3,07 \\
\hline LSD, P=5\% & 0,62 & 0,50 & 0,50 & 0,16 & 0,29 & \\
\hline
\end{tabular}

Na tablici vidimo da su plodovi istraživanih sorti postigli dobru kvalitetu. Utvrđene su stanovite razlike u količini topive suhe tvari, ukupnih šećera, reduktivnog šećera i ukupne kiseline, dok su razlike u količini saharoze vrlo male. Najveću količinu topive suhe tvari i šećera sadrže plodovi sorata Rexelle i Kelleris 14, a najmanju plodovi Oblačinske. Podjednaku količinu topive suhe tvari i šećera sadrže plodovi sorti Gorsemska i Heimannova konzervna. Utvrđena je statistički opravdana razlika u količini topive suhe tvari i šećera između sorti Rexelle i Kelleris 14 u odnosu na sorte: Gorsemska, Heimannova konzervna i Oblačinska. Manju i podjednaku količinu ukupne kiseline sadrže plodovi sorti Rexelle i Heimannova konzervna od sorata: Gorsemska, Kelleris 14 i Oblačinska, koje također sadrže podjednaku količinu ukupne kiseline. Između ove dvije skupine sorti razlika je statistički opravdana. Nije utvrđena veća razlika za $\mathrm{pH}$ vrijednost između istraživanih sorata. 


\section{RASPRAVA I ZAKLJUČCI}

Poznato je da klimatske prilike odražavaju znatan utjecaj na kemijski sastav plodova sorti višanja. Taj je utjecaj veći li manji ovisno os sortnim osobinama. Dakako, različit je utjecaj i pojedinih klimatskih faktora, a najviše temperatura u vrijeme zrenja. Razlike u kemijskom sastavu plodova mogu biti uvjetovane i količinom priroda. No, najveći utjecaj odražava sortno obilježje i klimatske prilike. Shala i Miljković (2002) utvrdili su osjetne razlike u kemijskom sastavu plodova sorti Rexelle, Kelleris 14 i Heimannova konzervna ovisno o klimatskim prilikama godine. Usporedimo li rezultate istraživanja, do kojih su pojedini autori došli tada vidimo da postoje velike razlike u količini ukupnih šećera $u$ plodovima jedne te iste sorte ovisno o ekologijskim uvjetima uzgojnog područja. Tako na primjer plodovi sorte Heimannova konzervna prema istraživanjima u ekološkim uvjetima sadrže manje ili više ukupnih šećera. U području Bjeline plodovi sadrže 8,55\% ukupnih šećera (N. Stajić, 1984.); u uvjetima Čačka 8,00\% (Lj. Janda, 1975.); u Timočkoj krajini 9,7\% (R. Miletić, 1991.), uvjetima Kosova 11,5\% (Shala i Miljković, 2002.), a prema našim istraživanjima u Slavoniji 8,58\%. Slične razlike u kemijskom sastavu plodova, ovisno u ekologijskim uvjetima, utvrđene su i za neke druge sorte. Kemijski sastav plodova Oblačinske višnje znatno se razlikuje ovisno o tipu i ekologijskim uvjetima uzgojnog područja. To su potvrdila istraživanja većeg broja istraživača. U Slavoniji je (B. Puškar, 2002) izdvojio 41 tip Oblačinske i obavio analizu kemijskog sastava njihovih plodova. Utvrdio je da postoje veće razlike u kemijskom sastavu plodova između istraživanih tipova. Tako se količina ukupnih šećera ovisno o tipu kretala u granici od 5,04\% do $11,3 \%$. Na temelju opsežnih istraživanja bioloških i gospodarskih osobina Puškar (2002.) je izdvojio 8 tipova Oblačinske (tipove: 1, 5, 6, 14, 20, 29, 38 i 41) i predložio uzgoj klonskog potomstva odabranih tipova. Na temelju provedenih istraživanja kemijskog sastava plodova mogu se izvesti zaključci.

Plodovi sorata višnje: Gorsemska, Rexelle, Kelleris 14, Heimannova konzervna i Oblačinska postižu dobru kvalitetu u ekologijskim uvjetima zapadne Slavonije. Veću topivi suhu tvar i šećere sadrže sorte Rexelle i Kelleris 14 od sorata: Gorsemska, Heimannova konzervna i Oblačinska. Između ove dvije skupine sorti razlika je statistički opravdana. Manju i podjednaku ukupnu količinu kiseline sadrže plodovi sorti Kelleris 14 i Heimannova konzervna od sorti: Gorsemska, Rexelle i Oblačinska. Između dvije skupine sorti razlika je statistički opravdana. Nije utvrđena veća razlika za pH vrijednost između istraživanih sorti. 


\section{LITERATURA}

JANDA, LJ., (1975.): Tehnološke karakteristike i pogodnosti ploda nekih sorti višanja za smrzavanje. Jug. voćarstvo, VIII, br. 31-32, p. 85-92.

MILETĆI, R., (1991.): Pomološko tehnološke karakteristike ploda nekih sorti višanja u Timočkoj krajini,. Jug. voćarstvo, 1-2, 39-43.

MILJKOVIĆ, I., (1991.): Suvremeno voćarstvo, Znanje, Zagreb.

PUŠKAR, B., (2002.): Inventarizacija i ocjena tipova Oblačinske višnje u cilju daljnje selekcije. Pomologia Croatica, Vol. 8, br. 1-14, p. 81-95.

STAJIĆ, N., (1984.): Pomološke karakteristike i kemijski sastav ploda važnijih sorti višanja. Jug. voćarstvo, 18, 69-70, p. 3-9.

ŠHALA, A., MILJKOVIĆ, I., (2002.): Istraživanje kemijskog sastava plodova višanja u ekologijskim uvjetima Kosova. Pomologia Croatica, Vol. 8, br. 14, p. 95-102.

\section{Adresa autora - Author's address:}

Prof. dr. sc. Ivo Miljković

10000 Zagreb, Čazmanska 2 
